University of Nebraska - Lincoln

DigitalCommons@University of Nebraska - Lincoln

Publications, Agencies and Staff of the U.S.

Department of Commerce

U.S. Department of Commerce

2011

\title{
Explaining spatial variability in stream habitats using both natural and management-influenced landscape predictors
}

\author{
K. J. Anlauf \\ Oregon Department of Fish and Wildlife, Kara.Anlauf-Dunn@oregonstate.edu \\ D. W. Jensen \\ K. M. Burnett \\ Oregon State University \\ E. A. Steel \\ USDA Forest Service
}

K. Christiansen

Oregon State University

See next page for additional authors

Follow this and additional works at: https://digitalcommons.unl.edu/usdeptcommercepub

Part of the Environmental Sciences Commons

Anlauf, K. J.; Jensen, D. W.; Burnett, K. M.; Steel, E. A.; Christiansen, K.; Firman, J. C.; Feist, B. E.; and Larsen, D. P., "Explaining spatial variability in stream habitats using both natural and managementinfluenced landscape predictors" (2011). Publications, Agencies and Staff of the U.S. Department of Commerce. 223.

https://digitalcommons.unl.edu/usdeptcommercepub/223

This Article is brought to you for free and open access by the U.S. Department of Commerce at DigitalCommons@University of Nebraska - Lincoln. It has been accepted for inclusion in Publications, Agencies and Staff of the U.S. Department of Commerce by an authorized administrator of DigitalCommons@University of Nebraska - Lincoln. 
Authors

K. J. Anlauf, D. W. Jensen, K. M. Burnett, E. A. Steel, K. Christiansen, J. C. Firman, B. E. Feist, and D. P. Larsen

This article is available at DigitalCommons@University of Nebraska - Lincoln: https://digitalcommons.unl.edu/ usdeptcommercepub/223 


\title{
Explaining spatial variability in stream habitats using both natural and management-influenced landscape predictors
}

\author{
K. J. ANLAUF ${ }^{\mathrm{a}, *}$, D. W. JENSEN ${ }^{\mathrm{b}}$, K. M. BURNETT ${ }^{\mathrm{c}}$, E. A. STEEL ${ }^{\mathrm{d}}$, K. CHRISTIANSEN ${ }^{\mathrm{c}}$, J. C. FIRMAN ${ }^{\mathrm{a}}$, B. E. FEIST \\ and D. P. LARSEN ${ }^{\mathrm{f}}$ \\ ${ }^{a}$ Corvallis Research Laboratory, Oregon Department of Fish and Wildlife, 28655 Hwy. 34, Corvallis, OR 97333, USA \\ b710 W. 27th Ave., Eugene, OR 97405, USA \\ ${ }^{\mathrm{C}}$ USDA Forest Service and Oregon State University, 3200 SW Jefferson Way, Corvallis, OR 97331, USA \\ ${ }^{\mathrm{d}}$ USDA Forest Service, PNW Research Station, 400 N34th Street, Suite 201, Seattle, WA 98103, USA \\ ${ }^{\mathrm{e}} \mathrm{NW}$ Fisheries Science Center, NOAA/ NMFS, Seattle, WA 98112, USA \\ ${ }^{\mathrm{f}}$ Pacific States Marine Fisheries Commission, c/o USEPA, Western Ecology Division, 200 SW 35th St., Corvallis, OR 97333, USA
}

\begin{abstract}
1. The distribution and composition of in-stream habitats are reflections of landscape scale geomorphic and climatic controls. Correspondingly, Pacific salmon (Oncorhynchus spp.) are largely adapted to and constrained by the quality and complexity of those in-stream habitat conditions. The degree to which lands have been fragmented and managed can disrupt these patterns and affect overall habitat availability and quality.

2. Eleven in-stream habitat features were modelled as a function of landscape composition. In total, 121 stream reaches within coastal catchments of Oregon were modelled. For each habitat feature, three linear regression models were applied in sequence; final models were composed of the immutable and management-influenced landscape predictors that best described the variability in stream habitat.

3. Immutable landscape predictors considered proxies for stream power described the majority of the variability seen in stream habitat features. Management-influenced landscape predictors, describing the additional human impacts beyond that which was inherently entwined with the immutable predictors, explained a sizeable proportion of variability. The largest response was seen in wood volume and pool frequency.

4. By using a sequential linear regression analysis, management-influenced factors could be segregated from natural gradients to identify those stream habitat features that may be more sensitive to land-use pressures. These results contribute to the progressing notion that the conservation of freshwater resources is best accomplished by investigating and managing stream systems from a landscape perspective.

Copyright (C) 2011 John Wiley \& Sons, Ltd.
\end{abstract}

Received 27 January 2011; Revised 7 July 2011; Accepted 7 August 2011

KEY WORDS: landscape scale; fish habitat; conservation evaluation; habitat management; monitoring; stream; coastal

\section{INTRODUCTION}

Conceptual and empirical approaches to understand and conserve fluvial ecosystems increasingly integrate the principals of landscape ecology (Johnson and Gage, 1997; Poole, 2002; Johnson and Host, 2010). These approaches become more pertinent and timely in the face of climate change and widespread human disturbance. Regional topography, geology, and climate regulate the structure and function of stream environments and are frequently used to model in-stream habitats (Allan, 2004; Kaufmann and Hughes, 2006) and biological patterns influenced by in-stream conditions (Richards et al., 1996; Steel et al., 2010). Efforts to understand these patterns have significantly advanced knowledge of how stream systems vary along longitudinal and lateral gradients, in addition to revealing landscape patterns relating to Pacific salmonid distribution (Steel et al., 2004; Isaak and Thurow, 2006; Burnett et al., 2007), abundance (Thompson and Lee, 2000; Pess et al., 2002), and recruitment (Thompson and Lee, 2002). The widespread degradation and

*Correspondence to: K. J. Anlauf, Corvallis Research Laboratory, Oregon Department of Fish and Wildlife, 28655 Hwy. 34 , Corvallis, OR 97333, USA. E-mail: Kara.Anlauf-Dunn@oregonstate.edu 
loss of freshwater habitats, contributing to the imperilment of aquatic species and decline of aquatic ecosystem integrity (Nehlsen et al., 1991; Master et al., 2000), in part motivates the recent proliferation of studies examining broad-scale associations among natural and modified landscapes, stream habitats, and salmonid populations.

Researchers continue to explore how relationships between the landscape and stream environment are generalized over large spatial domains and how these relationships can guide conservation efforts (Allan and Johnson, 1997; Spies et al., 2007) -for example, efforts to recover Pacific salmon target habitat rehabilitation over broad spatial scales. Given that the spatial extent of anadromous salmon life cycles span estuarine to headwater habitats, populations respond to regional processes and disturbances. Identifying relationships among in-stream conditions and landscape features can inform process-based restoration goals seeking to reestablish natural processes that form and modify in-stream habitats in response to human disturbance (Beechie et al., 2010). Owing to the co-varying nature of such landscape features and the extent of human disturbance, analytically flexible methods that account for and better manage inherent system variability are essential.

Quantifying the relationships among landscape patterns and in-stream habitat conditions is hindered by the spatial overlap among multiple landscape gradients. Scientists are challenged to understand how these confounding interactions affect stream habitats (Johnson and Host, 2010). The co-variation between landscape features makes it difficult to disassociate specific effects of modified or natural landscape features or to isolate pathways of influence over local habitat (Kaufmann and Hughes, 2006; Wang and Seelbach, 2006; Lucero et al., in press). The configuration and composition of these natural landscape features often influence the suitability and thereby the presence of particular land-use practices (Beschta et al., 1995; Allan, 2004).

Acknowledging that land use has been and continues to be inextricably linked to the landscape (Allan, 2004) will aid in developing analyses intending to differentiate between the myriad of landscape effects. The presence of multiple correlated predictors (multicollinearity) is analytically problematic as these tend to inflate the variance of coefficient estimates in regression analyses, reducing the reliability of explanatory models. Numerous techniques have been proposed to deal with this issue; residual regression, principal components regression, and hierarchical partitioning are a few alternatives (Mac Nally, 2002; Graham, 2003; King et al., 2005; Gromping, 2007). One of the proposed techniques partitions the relative importance of a set of collinear predictors on the response. This method assumes that some predictors are functionally more important and more mechanistically linked to the response (Graham, 2003), an assumption that also aligns with how in-stream habitats are formed and function. The nature of collinearity among natural and human factors can be incorporated in the development of explanatory models, which could improve the rigour and accuracy of modelling ecological relationships and aid in process-based restoration approaches.

The objectives in this study were (a) to evaluate how much in-stream habitat variation can be accounted for by landscape predictors, and (b) to determine whether a management-influenced signal, above and beyond that associated with immutable landscape predictors, can be detected. The approach in this study complements previous studies as it addresses the inherent correlation between the natural landscape and land use.

\section{MATERIALS AND METHODS}

\section{Study area}

The study area encompassed 121 coastal catchments in the Oregon Coastal Range (Figure 1) that are generally characterized by sedimentary or volcanic bedrock and elevations ranging from sea level to $380 \mathrm{~m}$. The area has a temperate maritime climate with mild, wet winters and dry summers. Coniferous forests, spanning early successional and old growth seral stages, dominate the study area, although broadleaf species such as big leaf maple (Acer macrophyllum) and red alder (Alnus rubra) are common. Inland species that predominate are Douglas fir (Psuedotsuga menziesii) and western hemlock (Tsuga heterophylla), while Sitka spruce (Picea sitchensis) prevails along the coast. Most of the province is privately owned by the forest industry and non-industrial forest owners; however, one third of the province is publicly managed by state or federal agencies (Spies et al., 2007). Disturbance regimes in this region include infrequent but intense wildfire, annual windstorms, landslides, timber harvest, and agriculture at the lower elevations (Burnett et al., 2007).

In general, stream flow in the Oregon Coast Range varies intra-annually but the pattern is relatively consistent across years. The majority of precipitation occurs as rainfall, with peak stream flows following winter rain storms and base flows occurring between July and October (Harr, 1976). The channel hydraulic characteristics vary with stream size and upslope catchment processes. Management activities affect catchment and channel hydraulics influencing peak flows, overland flows, and sedimentation rates (Harr, 1976). Five species of anadromous salmon reside in the study area: coastal cutthroat trout (Oncorhynchus clarki), Chinook salmon (Oncorhynchus tschawytscha), chum salmon (Oncorhynchus keta), steelhead (Oncorhynchus mykiss) and coho salmon (Oncorhynchus kisutch), which belong to the Oregon Coastal Coho Evolutionarily Significant Unit (ESU) (Weitkamp et al., 1995) listed as threatened under the US Endangered Species Act (1973).

\section{In-stream habitat data}

In-stream data for this study are from a coast-wide, integrated programme in Oregon to monitor adult coho salmon abundance, juvenile coho salmon abundance, and freshwater habitat (Firman and Jacobs, 2001). Potential sample reaches were selected using a generalized random tessellation stratified design to obtain a spatially balanced random sample (Stevens and Olsen, 2004). A rotating panel design, with rotations of 1 , 3 , and 9 years to correspond with the 3-year life cycle of coho salmon, was imposed to optimize status estimates and enable trend detection (Stevens and Olsen, 2004). In this analysis, only reaches surveyed annually and every 3 years were used.

Stream habitats were surveyed from mid-June to late September each year. Surveyed lengths for stream reaches were $500 \mathrm{~m}$ outside the current distribution of coho salmon and $1000 \mathrm{~m}$ for those inside the current distribution. Data 


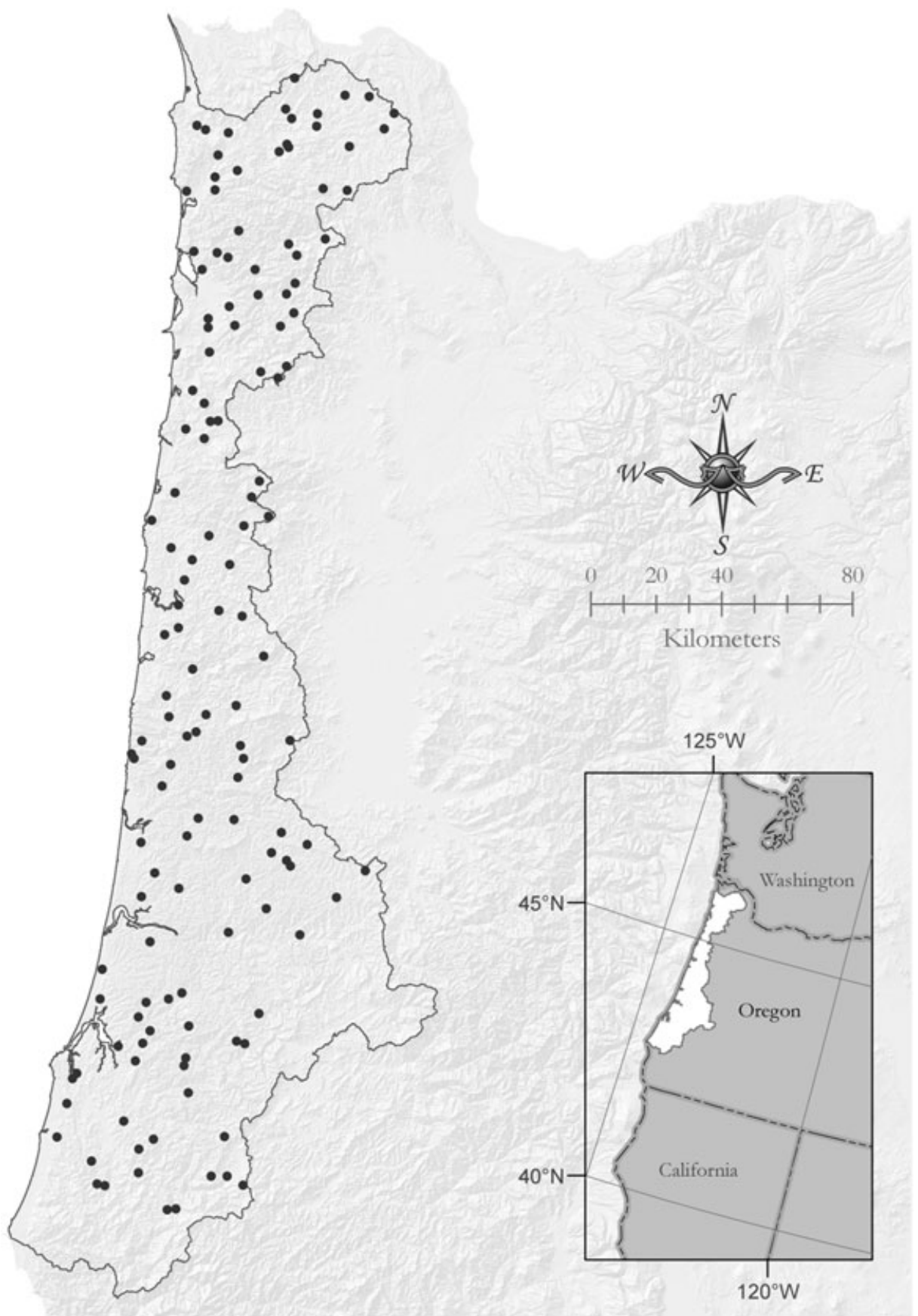

Figure 1. Distribution of in-stream habitat survey sites within the Oregon Coast Range.

were collected on specific features of the stream channel and the physical structure of the valley and riparian areas using methods described by Moore et al. (2007). Eleven in-stream habitat features were selected as response variables for analysis (Table 1). These are important habitat features in summer and reflect conditions limiting for coho salmon in winter.

A reach-level complexity feature is included to reflect potential interrelationships among in-stream habitat features and is consistent with other freshwater habitat complexity and diversity indices developed for similar reasons (Gorman and Karr, 1978; Nickelson and Lawson, 1998; Horan et al., 2000).
Five stream habitat features comprise the reach complexity feature: percentage secondary channel area, percentage pool habitat, number of pools, variance of residual pool depth, and pool diversity. Pool diversity was calculated as:

\section{$\mid(50-\mid(50-$ per cent of pool habitat in a reach $) \mid) \mid$}

which allows values to decrease on either side of 50, demonstrating an optimal balance between slow- (pool) and fast-water habitats. To standardize values for each of the five component habitat features, the mean and standard deviation were calculated across all reaches within a particular year, 
Table 1. All in-stream habitat features (response) used in the analyses. Values were summarized for a reach (500 $\mathrm{m}$ or $1000 \mathrm{~m})$ and averaged across years. Data were collected in the field using methods described in Moore et al. (2007)

\begin{tabular}{|c|c|c|}
\hline In-stream Habitat Feature & Description & $\begin{array}{c}\text { Data } \\
\text { Transformation }\end{array}$ \\
\hline Active Channel Width & Distance across the channel at bankfull flow (attained on average every 1.5 years) (m). & $\ln (x+1)$ \\
\hline $\begin{array}{l}\text { Percentage Secondary } \\
\text { Channel Area }\end{array}$ & Percentage of total reach area that is classified as secondary channel. & $\ln (x+1)$ \\
\hline Pools $/ 100 \mathrm{~m}$ & Pools per $100 \mathrm{~m}$ of reach length. & $\ln (x+1)$ \\
\hline Residual Pool Depth & The difference of max depth and pool tail crest (meters). & $\ln (x+1)$ \\
\hline Valley Width Index (VWI) & $\begin{array}{l}\text { Average Valley Width Index for the reach; VWI equates to the total number of active channel widths } \\
\text { that will fit between each hillslope. }\end{array}$ & $\ln (x+1)$ \\
\hline $\begin{array}{l}\text { Percentage Undercut } \\
\text { Banks }\end{array}$ & Percentage of the perimeter of the habitat unit composed of undercut banks. & $\ln (x+1)$ \\
\hline Percentage Shade & Percentage of the stream channel that is shaded. & $\operatorname{Logit}(x)$ \\
\hline Percentage Fine Sediments & Proportion of the stream-bed area that is classified as silt, sand, and organics $(<2 \mathrm{~mm})$. & $\ln (x+1)$ \\
\hline Percentage Gravel & Proportion of the stream-bed area that is classified as gravel $(2-64 \mathrm{~mm})$. & N/A \\
\hline Wood Volume & Volume of in-stream wood per $100 \mathrm{~m}$ of reach length $\left(\mathrm{m}^{3}\right.$ per $\left.100 \mathrm{~m}\right)$ & $\ln (x+1)$ \\
\hline Reach Level Complexity & $\begin{array}{l}\text { The sum of secondary channel area, number of pools, the variance of residual pool depths, and a } \\
\text { pool diversity metric. The diversity metric is calculated by subtracting } 50 \text { from the percentage of } \\
\text { pools in a reach. Standardized across all years and all sites. }\end{array}$ & $\mathrm{N} / \mathrm{A}$ \\
\hline
\end{tabular}

and then for each reach the mean was subtracted from the reach value and divided by the standard deviation. The five standardized values for each reach were summed to create the reach-level complexity feature.

\section{Landscape predictors}

Geospatial data layers, reflecting landform and human influences on local in-stream habitats, provided the landscape predictors (Table 2). Each predictor was summarized for the catchment flowing into each study reach, which encompassed the entire drainage area upstream. Immutable landscape predictors are relatively unaffected by human influence (gradient, precipitation, drainage area, elevation, flow, temperature, geology) and management-influenced landscape predictors are affected by or are a direct result of human influence (forest cover, land ownership, disturbance, and land use) (Table 2).

\section{Model development and statistical analysis}

Each of the 11 in-stream habitat features was regressed against multiple immutable and management-influenced landscape predictors using Proc GLM in SAS. Because temporal variability was low (Anlauf et al., 2011), in-stream habitat data were averaged across the 10 years for which data were available and mean values were used as regression responses. To improve model fit, a habitat feature was transformed if its distribution departed sufficiently from normal. A sequential regression approach was used (Graham, 2003; Kaufmann and Hughes, 2006). In the first step, in-stream habitat features were regressed against immutable landscape predictors indicative of stream power (gradient, drainage area, precipitation, and their natural log counter-part) (Table 2), which are first-order controls that determine the amount and size of material that flowing water can transport. These three predictors are related to many in-stream habitat variables (Kaufmann and Hughes, 2006; Johnson and Host, 2010). In the next step, additional immutable landscape predictors (Table 2) were added to the best stream power indicators for each in-stream habitat feature. In the final step, management-influenced landscape predictors (Table 2) were added to the best immutable landscape predictors identified in the two preceding steps.

At each step in the regression sequence for each in-stream habitat response, one and two landscape predictor combinations were evaluated (see below) before the third and final landscape predictor was added to a model. Akaike Information Criterion (AIC) was used to select the final model from a set of competing models at each step. Models with $\triangle \mathrm{AIC}\left(\mathrm{AIC}_{\text {model }}-\mathrm{AIC}_{\text {null }}\right.$ model $)$ less than 4 as competing models were considered (Burnham and Anderson 2002). Only models with a condition index (Belsley et al., 1982) less than 25 were included in the original candidate pool to avoid serious collinearity problems that can inflate variance estimates and affect model reliability (Ott and Longnecker, 2001). Only models with a Cook's D (Cook, 1977) less than 1 were included in the original candidate pool to eliminate instability due to data points with high leverage. When the best model identified by AIC did not meet these additional criteria, the next model in ascending AIC that met the criteria was chosen. The final 11 models were cumulative, composed of the immutable and management-influenced landscape predictors that met the above criteria.

The $\Delta$ Adjusted $\mathrm{R}^{2}$ was used to calculate the difference in the coefficient of determination with the addition of (1) the immutable predictors, and (2) the management-influenced predictors. To determine the specific contribution of management-influenced landscape predictors, while all other immutable predictors were held constant, the coefficient of partial determination (partial $\mathrm{R}^{2}$ ) was calculated.

\section{Model diagnostics and collinearity}

To evaluate model predictions, correlations were examined between predicted and observed values for each habitat feature. Variance inflation factors (VIFs) were calculated to detect multi-collinearity among immutable and management-influenced landscape predictors in the final model for each in-stream habitat feature. A VIF value greater than 5 indicates a serious collinearity problem (Ott and Longnecker, 2001). 
Table 2. Description of geospatial landscape predictors used in the regression analysis

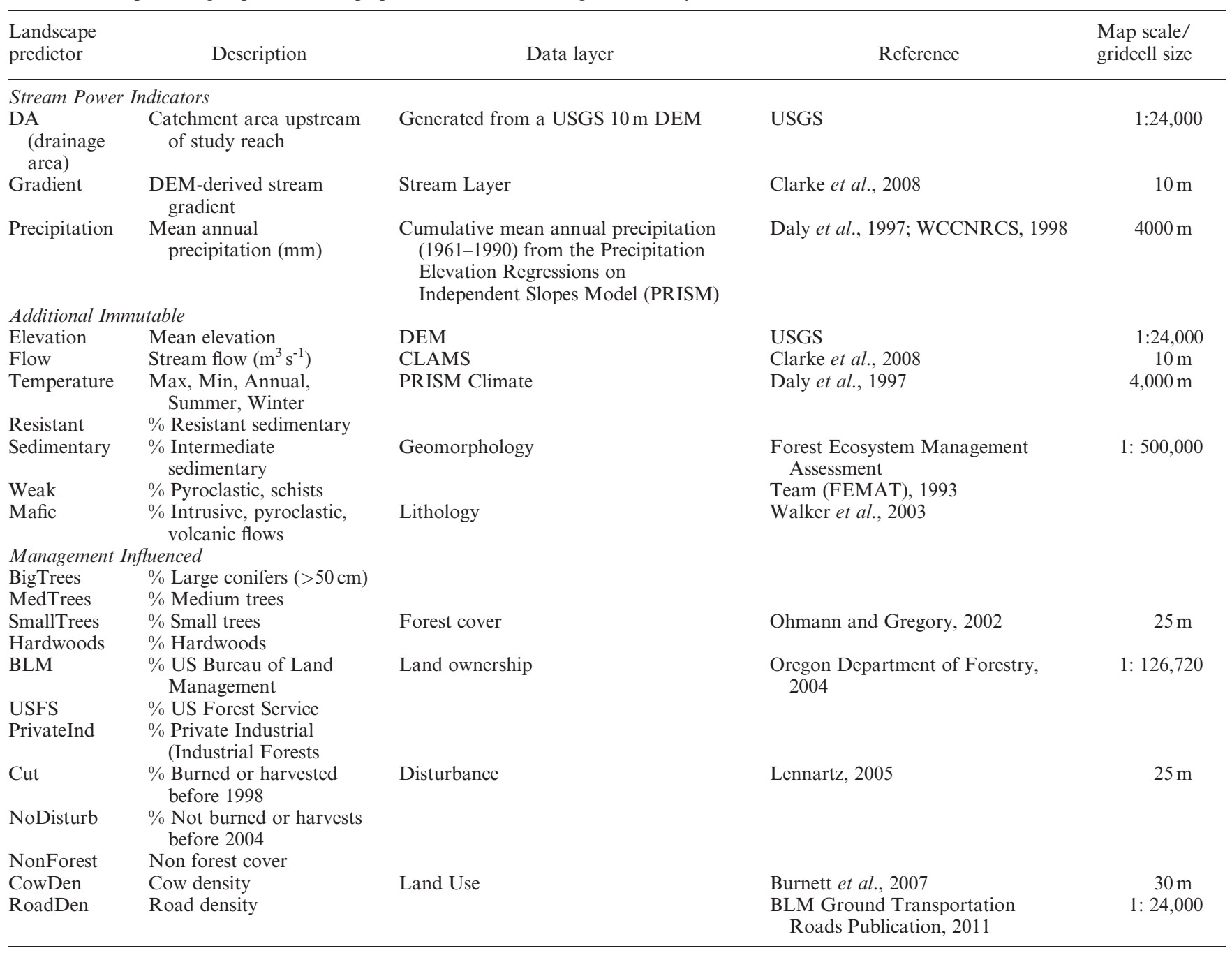

\section{RESULTS}

\section{Variation explained by landscape predictors}

\section{Immutable predictors}

The variation in habitat features explained by gradient, precipitation, and/or drainage area ranged from 0.05 to 0.72 (Table 3; Figure 2). Active channel width (Adjusted $\mathrm{R}^{2}=0.72$ ) and percentage of fine sediments (Adjusted $\mathrm{R}^{2}=0.48$ ), which are expected to be largely influenced by the stream power indicators, had the highest adjusted $\mathrm{R}^{2}$ values. Those least correlated with these landscape predictors were percentage gravel (Adjusted $\mathrm{R}^{2}=0.05$ ), pools per $100 \mathrm{~m}$ (Adjusted $\mathrm{R}^{2}=0.11$ ), and percentage secondary channel area (Adjusted $\left.\mathrm{R}^{2}=0.12\right)$. The additional variation in habitat features explained by immutable landscape predictors representing elevation, flow, temperature, and geology ranged from 0.001 to 0.08 , with the largest increase for wood volume (Table 3 ; Figure 2). Landscape habitat predictors characterizing geology explained most of the additional variation associated with this suite of immutable predictors. Of the final models for the 11 in-channel habitat features, fewer than half included elevation or flow but none included temperature predictors.

\section{Management-influenced predictors}

Management-influenced predictors explained up to $16 \%$ additional variation in habitat features (Table 3; Figure 2). After accounting for immutable predictors, partial $\mathrm{R}^{2}$ values were highest for pools per $100 \mathrm{~m}\left(\right.$ partial $\mathrm{R}^{2}=0.21$ ) and wood volume (partial $\mathrm{R}^{2}=0.28$ ). Wood volume was associated with several landscape predictors reflecting wood availability ( $\%$ non-forest, $\%$ small trees, and $\%$ remnant forests), whereas pools per 100-m was associated with disturbances affecting pool retention (cow density, road density) and pool formation ( $\%$ small trees).

\section{Model diagnostics and collinearity}

Predicted versus observed responses were correlated, with r-values ranging from $0.419-0.866$ (Table 4) and predicted values varying spatially (Figure 3). Variance inflation factors (VIF) indicated low collinearity among landscape predictors in the final models; $100 \%$ of the predictors had 
Table 3. Final model equations for each in-stream habitat feature response once immutable and management-influenced landscape predictors were added to models fitted with stream power indicators. AdjR $\mathrm{R}^{2}=$ Adjusted $\mathrm{R}^{2}$

\begin{tabular}{|c|c|c|c|c|c|}
\hline Response & Model & $\operatorname{Adj}_{1}^{2}$ & $\begin{array}{l}\text { partial } \\
\mathrm{R}_{2}^{2}\end{array}$ & $\begin{array}{l}\text { partial } \\
\mathrm{R}_{3}^{2}\end{array}$ & $\operatorname{Adj}_{4}^{2}$ \\
\hline $\begin{array}{l}\text { Active Channel } \\
\text { Width }\end{array}$ & $\begin{array}{l}1.122+(0.00019 * \text { Precip }+0.384 * \operatorname{lnDA})-(0.0025 * \text { Sedimentary })- \\
\quad\left(0.0091 * \text { Hardwoods }-0.061 * \text { RoadDen }+0.0033^{*} \text { Cut }\right)\end{array}$ & 0.716 & 0.035 & 0.072 & 0.737 \\
\hline $\begin{array}{l}\text { Percentage } \\
\text { Secondary } \\
\text { Channel Area }\end{array}$ & $\begin{array}{l}0.569+(0.112 * \ln \text { Gradient }+0.00021 * \text { Precip }+0.074 * \ln D A)- \\
\quad(0.0027 * \text { Sedimentary })-(0.019 * \text { NonForest })\end{array}$ & 0.124 & 0.013 & 0.021 & 0.139 \\
\hline Pools/100 m & $\begin{array}{l}1.255-(0.0269 * \text { Gradient }-0.0284 * \operatorname{lnDA})+(0.00050 * \text { Elev }-0.0017 * \text { Flow }- \\
0.0023 * \text { Weak })+(0.107 * \text { RoadDen }-0.0094 * \text { SmallTrees }-0.0054 * \text { CowDensity })\end{array}$ & 0.112 & 0.124 & 0.210 & 0.336 \\
\hline Residual Pool Depth & $\begin{array}{l}-0.824-(0.0343 * \text { Gradient }+0.00011 * \text { Precip }+0.060 * \operatorname{lnDA})- \\
\quad(0.0008 * \text { Sedimentary })-(0.0048 * \text { Remnant }+0.049 * \text { RoadDen }- \\
\quad 0.0097 * \text { NonForest })\end{array}$ & 0.266 & 0.009 & 0.090 & 0.316 \\
\hline VWI Reach & $\begin{array}{l}2.171-(0.441 * \operatorname{lnG} \text { Gradient }-0.210 * \ln \mathrm{DA})-(0.0015 * \text { Resistant }+0.0041 * \mathrm{BLM} \\
\quad+0.023 * \text { NonForest }-0.0084 * \text { SmallTrees })\end{array}$ & 0.268 & 0.011 & 0.082 & 0.313 \\
\hline $\begin{array}{l}\text { Percentage Undercut } \\
\text { Banks }\end{array}$ & $\begin{array}{l}2.561-\left(0.102 * \text { Gradient }+8.957 * 10^{-5} * \text { Precip }-0.219 * \operatorname{lnDA}\right)-(0.0030 * \text { Flow }- \\
0.0039 * \text { Resistant }-0.0043 * \text { Weak })-(0.0163 * \text { CowDensity }-0.0111 * \text { SmallTrees } \\
\quad+0.138 * \text { RoadDen })\end{array}$ & 0.335 & 0.091 & 0.122 & 0.422 \\
\hline $\begin{array}{l}\text { Percentage Fine } \\
\text { Sediments }\end{array}$ & $\begin{array}{l}5.255-(0.568 * \operatorname{lnG} \text { Gradient }-0.0002 * \text { Precip }-0.444 * \operatorname{lnDA})-0.003 * \text { Resistant }- \\
0.021 * \text { NonForest }-0.0063 * \text { SmallTrees }\end{array}$ & 0.479 & 0.052 & 0.064 & 0.526 \\
\hline Percentage Gravel & $\begin{array}{l}23.023-(1.267 * \text { Gradient }-3.908 \\
\quad * \operatorname{lnDA})+(0.0488 * \text { Flow }+0.0632 * \text { Resistant })+(0.105 * \text { BLM }- \\
\quad 0.136 * \text { NoDisturb }+0.135 * \text { BigTrees })\end{array}$ & 0.047 & 0.042 & 0.096 & 0.134 \\
\hline Wood Volume & $\begin{array}{l}2.024+(0.382 * \operatorname{lnGradient})+(0.0016 * \text { Elev }+0.0028 * \text { Resistant }+0.0024 * \text { Flow })- \\
\quad(0.085 * \text { NonForest }-0.0091 * \text { SmallTrees }+0.009 * \text { Remnant })\end{array}$ & 0.301 & 0.164 & 0.279 & 0.544 \\
\hline $\begin{array}{l}\text { Reach Level } \\
\text { Complexity }\end{array}$ & $\begin{array}{l}-3.514-(0.221 * \text { Gradient }+0.00077 * \text { Precip }+0.342 * \operatorname{lnDA})- \\
\quad(0.00074 * \text { Elev })+(0.0186 * \text { NoDisturb }+0.288 * \text { RoadDen }+0.010 * \text { BLM })\end{array}$ & 0.346 & 0.029 & 0.106 & 0.410 \\
\hline
\end{tabular}

${ }_{1}$ Adjusted R-square for stream power immutable landscape predictors representing indicators of stream power.

${ }_{2}$ Coefficient of partial determination for additional immutable predictors after accounting for gradient, precipitation and drainage area.

${ }_{3}$ Coefficient of partial determination for management-influenced predictors after accounting for all immutable predictors.

${ }_{4}$ Final Adjusted R-square value.

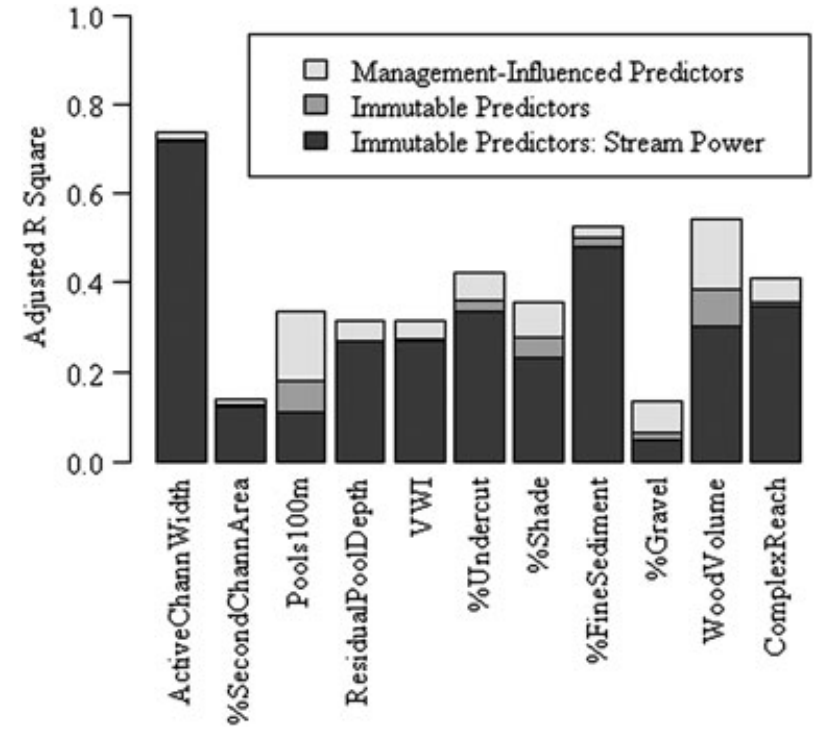

Figure 2. Proportion of variability attributed to managementinfluenced predictors, immutable predictors (climate, geology, topography), and stream power indicators (gradient, precipitation, drainage area) for the 11 in-stream habitat response features evaluated.

VIF values less than 5 and $80 \%$ were less than 2 . However, the co-occurrence of certain landscape predictors (e.g. drainage area with gradient or flow) repeatedly produced VIF values greater than 2.5 .

\section{DISCUSSION}

One of the central goals in this study was to account for natural gradients, enabling a better understanding of the management-influenced effects on stream habitats as a basis for conserving freshwater ecosystems. After accounting for landscape predictors representing stream power, results of this study indicate that other immutable landscape predictors explained little in-stream habitat variation, and adding management-influenced predictors explained up to $28 \%$ (partial $\mathrm{R}^{2}$ ) more variation. This result shows the substantial influence recent and historical land management can have on stream habitat beyond that of natural gradients. This study summarizes habitat conditions that are predominantly constrained by topographic and climatic gradients but have variable sensitivity to land-use pressures. Our approach to landscape partitioning in this study can help determine the degree of human influence among in-stream habitat metrics, providing a foundation for managers to understand stream condition in the context of the landscape, and prescribe the appropriate restoration. The focus of this discussion will be on those habitat metrics that were best modelled using these methods and most relevant in terms of ecological process and biological significance.

\section{Influence of land management on in-stream habitat}

For some in-stream habitat features, longitudinal controls expressed by topographic and geomorphic landscape features may be more important than predictors reflecting current 
SPATIAL VARIABILITY IN STREAM HABITATS

Table 4. Predicted mean value with associated root mean square error (RMSE) for in-stream habitat response features and corresponding 95\% confidence intervals ( \pm 2 (RMSE)). Correlations between observed and predicted in-stream habitat response features also calculated

\begin{tabular}{|c|c|c|c|c|c|c|}
\hline \multirow[b]{2}{*}{ Response } & \multirow{2}{*}{$\begin{array}{l}\text { Observed } \\
\text { mean }\end{array}$} & \multirow{2}{*}{$\begin{array}{l}\text { Predicted } \\
\text { mean }\end{array}$} & \multirow[b]{2}{*}{ Correlation } & \multirow[b]{2}{*}{ RMSE } & \multicolumn{2}{|c|}{$95 \%$ Confidence interval } \\
\hline & & & & & Lower & Upper \\
\hline Percentage Secondary Channel Area (log) & 1.048 & 0.734 & 0.419 & 0.632 & -0.216 & 2.312 \\
\hline Pools/100 m (log) & 1.100 & 1.345 & 0.617 & 0.286 & 0.528 & 1.672 \\
\hline Residual Pool Depth (log) & -0.607 & -0.764 & 0.596 & 0.295 & -1.197 & -0.017 \\
\hline VWI Reach $(\log )$ & 1.300 & 1.537 & 0.589 & 0.630 & 0.040 & 2.560 \\
\hline Percentage Shade (logit) & 1.863 & -0.314 & 0.626 & 0.977 & -0.091 & 3.817 \\
\hline Percentage Fine Sediments (log) & 3.163 & 4.210 & 0.741 & 0.517 & 2.129 & 4.197 \\
\hline Percentage Gravel & 28.617 & 33.219 & 0.430 & 13.598 & 1.421 & 55.813 \\
\hline Wood Volume (log) & 2.690 & 2.328 & 0.755 & 0.690 & 1.310 & 4.070 \\
\hline Reach Level Complexity & -0.082 & -3.074 & 0.667 & 1.526 & -3.134 & 2.9699 \\
\hline
\end{tabular}

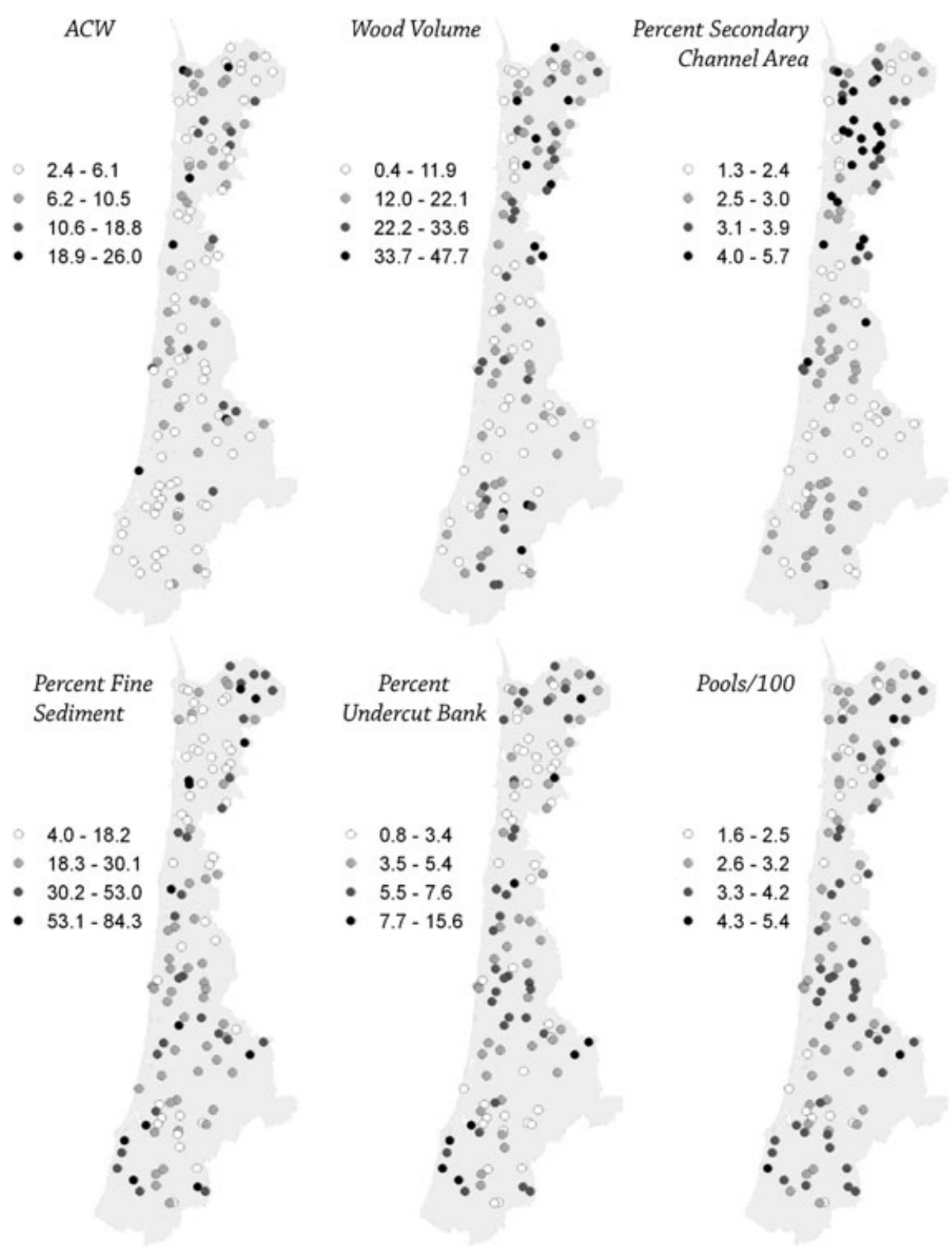

Figure 3. Spatial representation of predicted values for six of the in-stream habitat response features.

human influence. Consistent with this, management-influenced predictors explained little variation in active channel width or percentage fine sediment beyond that of natural gradients already incorporated in the sequentially fitted models. Several studies have identified similar immutable predictors as primary drivers of sediments or geomorphic conditions 
describing stream size (e.g. pool volume or depth) Burnett et al., 2006; Jorgensen et al., 2009). Much of the current research has shown that sediment dynamics in streams is sensitive to land use and management (Wood and Armitage, 1997; Kaufmann et al., 2008; Larsen et al., 2008). While the human activities that widen stream channels and exacerbate in-stream sedimentation do occur in the study area, the effects of these activities may co-vary with the stronger signals of stream power and other immutable landscape predictors (Lucero et al., in press). These two features are commonly monitored in habitat monitoring programmes (Roper et al., 2010) and are useful and pertinent for monitoring goals that often vary across agencies and regions.

Although immutable landscape predictors explained a large percentage of the variation in wood volume, management-influenced predictors accounted for over a quarter of the total. The positive relationships between immutable landscape features and in-stream wood have been noted before (Burnett et al., 2007; Lucero et al., in press) and are probably a result of the spatial scale at which the landscape data were summarized, and the location of the study reaches relative to that extent. While the results are the inverse of what is expected in relation to stream power, the use of a sequential regression approach partitioned landscape features making the results comprehensible in the context of land management in the Oregon Coast Range. As Lucero et al. (in press) noted, larger spatial scales will tend to include higher elevations and gradients, and more mature forest. The predictors related to forest composition, representing upslope conditions influencing wood recruitment in streams, emerged as the strongest correlates. Wood volumes varied as catchments became less forested and were harvested and replanted. Other studies have noted in-stream reductions in both the condition of large wood and the resulting habitats it fosters (Al-Chokhachy et al., 2010), and wood recruitment as a result of forest practices (Wing and Skaugset, 2002; Czarnomski et al., 2008). Given that in-stream wood is sensitive to management and is a catalyst for direct and indirect influences on sediment transport and storage, stream stability, and complexity for salmonids (Montgomery and Piegay, 2003), it is a particularly useful indicator of human disturbance. However, to contribute more fully to recovery goals in the Oregon Coast Range and elsewhere, one should consider both the complexity of the coastal geomorphology and the landscape mosaic of forest management affecting fluvial processes that drive in-stream wood dynamics. Considering the role of in-stream wood relative to disturbances upstream may make this frequently measured feature within monitoring programmes (Roper et al., 2010) more pertinent and effective in implementing restoration and monitoring.

\section{Habitat features insensitive to either immutable or management variables}

Several in-stream habitat features (e.g. pool frequency, residual pool depth, percentage gravel, secondary channel area) were poorly explained by landscape predictors in this study. Reasons for this include mismatches in the scale of analysis with some relationships possibly perceivable at finer or coarser scales than those examined (Lucero et al., in press), need for a multi-scale approach (Feist et al., 2003; Lowe et al., 2006), and differing patterns of disturbance across catchments. Regarding the last of these, Roper et al., (2007) also had difficulties relating stream habitat features to vegetative disturbance, a result they attribute in part to the differences between patterns of natural and human disturbance. The frequency and intensity of natural disturbances (e.g. fires and landslides), can be exacerbated by past and present land use (e.g. timber harvest and persistence of non-forest) (Stanley et al., 2010). Several studies have successfully evaluated these broad-scale relationships to in-stream habitat when managed and un-managed (reference) catchments can be distinguished (Kershner et al., 2004; Al-Chokhachy et al., 2010). In the Oregon Coast Range, however, few reference catchments are available given extensive contemporary or historical human disturbances. The degree to which historical land-use has affected stream habitat features is neither well documented nor understood and could hamper abilities to detect relationships with variables reflecting current management. Historical land-use can influence stream conditions long after the disturbance has ceased, modifying stream habitat and biotic community structure and diversity (Harding et al., 1998; Maloney et al., 2008; Zhang et al., 2009). The legacy of splash dams (Miller, 2010) and mill dams (Walter and Merritts, 2008) in the Oregon Coast Range and elsewhere illustrate how historical disturbance has homogenized stream channels, altered floodplain sedimentation, and modified the perception of natural channel geometry. Further research on legacy effects and disturbance thresholds on stream habitats and fish species would provide insight into future studies seeking to appreciate these landscape linkages.

Many of the in-stream habitat metrics evaluated here relate directly to the quality of fish habitat (McMahon and Hartman, 1989) and so are commonly measured in monitoring programmes (Roper et al., 2010), and are often the target of restoration measures (e.g. wood placement to accumulate gravels, form pools, and increase area in secondary channels). When evaluating habitat metrics to include or retain in a monitoring programme, important considerations include the pertinence of the metric to fish, its spatial and temporal variability across the landscape, as well as its sensitivity to management. For example, only a small proportion of the variation in pool habitat was explained by landscape features $\left(\operatorname{Adj} R^{2}=0.34\right)$, but management-influenced predictors did account for the majority (60\% of the total). Alternatively, the percentage of gravel substrates and secondary channel area, which are regularly monitored, could not be usefully explained by landscape features. This could be due to the common but patchy nature of gravel-bed substrates and the increasingly rare presence of secondary channels and off-channel habitats. Given these results, perhaps these two metrics are ill suited for understanding associations across the landscape or may be better incorporated into an integrated metric with other local habitat attributes.

\section{Measure of stream complexity}

Integrating multiple stream habitat features into a single metric or index has proved valuable when trying to understand and describe occupancy (Gorman and Karr, 
1978) and abundance (Horan et al., 2000; Hasegawa and Maekawa, 2008). Although habitat complexity ensures the diversity of fish communities (Smokorowski and Pratt, 2007) and can thwart the persistence of non-native species (Rich et al., 2003), few studies have evaluated the landscape effects on in-stream habitat complexity. One exception is a recent study by Al-Chokhachy et al. (2010) who used a multimetric index approach when evaluating the effects of management activities on habitat condition. They found that habitat index values were significantly related to land management predictors of road density and grazing. In the current study, immutable landscape predictors describing stream power explained most of the variation in the pool complexity habitat feature with relatively little variance accounted for by adding management-influenced predictors to the model. This result was somewhat unexpected given that the reduction of complex habitat structure and the simplification of channel habitats are a result of land management, and has been noted as one of the bottlenecks to the recovery of Oregon coast coho salmon (NOAA, 1997; OCSRI, 1997). Perhaps a more comprehensive complexity metric, versus one limited to pool habitats alone, would be more informative in the context of these data.

\section{Study implications and conclusions}

One of the primary purposes of correlative studies is to further understanding on how in-stream habitats are influenced by landscape controls at broad spatial extents, which is often impractical using controlled experiments. Relationships identified in these studies may generate testable hypotheses about landscape controls on habitat but have immediate value in suggesting landscape features important for conserving critical salmon habitats. This is important to more effectively meet recovery and conservation goals. In addition, these relationships can help inform monitoring strategies for adult and juvenile salmon whose occupancy may be driven directly by in-stream conditions. Results of this study can guide restoration efforts in times of tight budget by suggesting activities and areas that have the greatest likelihood to yield improvements. Similarly, targeting those in-stream habitat metrics that seem to be more sensitive to management may also be those that are sensitive to restoration measures. Restoration efforts are often focused on improving habitat conditions in general, and specifically for juvenile salmonid species. However, identifying areas that benefit multiple salmonid life stages may ensure long-term population viability. Habitat colonization and expansion of geographic distributions is important to the evolutionary sustainability of a population (Anderson and Quinn, 2007). Describing how variability in stream habitats can be partitioned among landscape predictors is particularly applicable when assessing the population status of coho salmon whose most suitable habitats, characterized by low stream gradients in low valley slopes, are also where human influences tend to be concentrated (Giannico, 2000; Sharma and Hilborn, 2001; Burnett et al., 2007). Understanding the relationships that currently exist among in-stream habitat and management-influenced landscapes will aid in understanding how current and natural processes differ. Ultimately, these results can be used to set goals in stream restoration that enhance ecosystem processes with a focus on sustaining fish populations under changing climate and ocean regimes.

\section{ACKNOWLEDGEMENTS}

We thank Dr. John Stein at the Northwest Fisheries Science Center, Seattle, WA, Aquatic Conservation editor Professor Philip Boon, and one anonymous reviewer for their constructive suggestions. We would also like to acknowledge and thank the field crews who collected the wealth of habitat data. This work was funded by a grant from the Oregon Watershed Enhancement Board with additional support from NOAA's Northwest Fisheries Science Center and the USDA Forest Service Pacific Northwest Research Station.

\section{REFERENCES}

Allan JD. 2004. Landscape and riverscapes: the influence of land use on stream ecosystems. Annual Review of Ecological and Evolutionary Systems 35: 257-284.

Allan JD, Johnson LB. 1997. Catchment-scale analysis of aquatic ecosystems. Freshwater Biology 37: 107-111.

Al-Chokhachy R, Roper BB, Archer EK. 2010. Evaluating the status and trends of physical stream habitat in headwater streams within the Interior Columbia River and Upper Missouri River Basins using an index approach. Transactions of the American Fisheries Society 139: 1041-1059.

Anderson JH, Quinn TP. 2007. Movements of adult coho salmon (Oncorhynchus kisutch) during colonization of newly accessible habitat. Canadian Journal of Fisheries and Aquatic Sciences 64: 1143-1154.

Anlauf KJ, Gaueman W, Jones KK. 2011. Detection of regional trends in salmonid habitat in coastal streams, Oregon. Transactions of the American Fisheries Society 140: 52-66.

Beechie TJ, Sear DA, Olden JD, Pess GR, Buffington JM, Moir H, Roni P, Pollock MM. 2010. Process-based principles for restoring river ecosystems. BioScience $\mathbf{6 0}$ : 209-222.

Belsley DA, Kuh E, Welsch RE. 1982. Regression Diagnostics: Identifying Influential Data and Sources of Collinearity. John Wiley: New York.

Beschta RL, Frissell CA, Gresswell RG, Hauer R, Karr JR, Minshall GW, Perry DA, Rhodes JJ. 1995. Wildfire and salvage logging: recommendations for ecologically sound post-fire salvage management and other post-fire treatments on federal lands in the west. http:// pacificrivers.org/science-research/resources-publications/ wildfire-and-salvage-logging-the-beschta-report. March 1995.

Bureau of Land Management (BLM). 2011. http://www.blm. gov/or/gis/data-details.php?data=ds000041 [18 May 2011].

Burnett KM, Reeves GH, Miller DJ, Clarke S, Vance-Borland K, Christiansen K. 2007. Distribution of salmon-habitat potential relative to landscape characteristics and implications for conservation. Ecological Applications 17: 66-80.

Burnett KM, Reeves GH, Clarke SE, Christiansen KR. 2006. Comparing riparian and catchment influences in stream habitat in a forested, montane landscape. In Landscape influences on stream habitats and biological assemblages, Hughes RM, Wang L, Seelbach PW (eds). American Fisheries Society, Symposium 48, Bethesda: Maryland; 175-197. 
Burnham KP, Anderson DR. 2002. Model Selection and Multimodel Inference: A Practical Information-Theoretic Approach. Springer-Verlag: New York.

Clarke SE, Burnett KM, Miller DJ. 2008. Modeling streams and hydrogeomorphic attributes in Oregon from digital and field data. Journal of the American Water Resources Association 44: 1-20.

Cook RD. 1977. Detection of influential observations in linear regression. Technometrics 19: 15-18.

Czarnomski NM, Dreher DM, Snyder KU, Jones JA, Swanson FJ. 2008. Dynamics of wood in stream networks of the western Cascades Range, Oregon. Canadian Journal of Forestry Research 38: 2236-2248.

Daly C, Taylor GH, Gibson WP. 1997. The PRISM approach to mapping precipitation and temperature. In 10th Conference on Applied Climatology. American Meteorological Society: Reno, NV; 10-12.

Feist BE, Steel EA, Pess GR, Bilby RE. 2003. The influence of scale on salmon habitat restoration priorities. Animal Conservation 6: 271-282.

Firman JC, Jacobs SE. 2001. A survey design for integrated monitoring of salmonids. Proceedings of the First International Symposium on Geographic Information Systems (GIS) in Fishery Science, Nishida T, Kailola PJ, Hollingworth CE (eds). Fishery GIS Research Group: Saitama, Japan; 242-252.

Forest Ecosystem Management Assessment Team (FEMAT). 1993. Forest Ecosystem Management: An Ecological, Economic, and Social Assessment. US Department of the Interior: Portland, OR.

Giannico GR. 2000. Habitat selection by juvenile coho salmon in response to food and woody debris manipulations in suburban and rural stream sections. Canadian Journal of Fisheries and Aquatic Sciences 57: 1804-1813.

Gorman OT, Karr JR. 1978. Habitat structure and stream fish communities. Ecology 59: 507-515.

Graham MH. 2003. Confronting multicollinearity in ecological multiple regression. Ecology 84: 2809-2815.

Gromping U. 2007. Estimators of relative importance in linear regression based on variance decomposition. The American Statistician 61: 139-147.

Harding JS, Benfield EF, Bolstad PV, Helfman GS, Jones III EBD. 1998. Stream biodiversity: the ghost of land use past. Proceedings of the National Academy of Sciences 95: 14843-14847.

Harr RD. 1976. Hydrology of Small Forest Streams in Western Oregon. US Forest Service: Portland, OR.

Hasegawa K, Maekawa K. 2008. Interference competition between native and non-native salmonid species. Canadian Journal of Zoology 86: 386-393.

Horan DL, Kershner JL, Hawkins CP, Crowl TA. 2000. Effects of habitat area and complexity on Colorado River cutthroat trout density in Uinta Mountain streams. Transactions of the American Fisheries Society 129: $1250-1263$.

Isaak DJ, Thurow RF. 2006. Network-scale spatial and temporal variation in Chinook salmon (Oncorhynchus tshawytscha) redd distributions: patterns inferred from spatially continuous replicate surveys. Canadian Journal of Fisheries and Aquatic Sciences 63: 285-296.

Johnson LB, Gage GE. 1997. Landscape approaches to the analysis of aquatic ecosystems. Freshwater Biology 37: $113-132$.

Johnson LB, Host SH. 2010. Recent developments in landscape approaches for the study of aquatic ecosystems. Journal of the North American Benthological Society 26: 41-66.

Jorgensen JC, Honea JM, McClure MM, Cooney TD, Engie K, Holzer DM. 2009. Linking landscape-level change to habitat quality: an evaluation of restoration actions on the freshwater habitat of spring-run Chinook salmon. Freshwater Biology 54: 1560-1575.

Kaufmann PR, Hughes RM. 2006. Geomorphic and anthropogenic influences on fish and amphibians in Pacific Northwest coastal streams. American Fisheries Society Symposium 48: 429-455.

Kaufmann PR, Larsen DP, Faustini JM. 2008. Bed stability and sedimentation associated with human disturbances in Pacific Northwest streams. Journal of the American Water Resources Association 45: 434-459.

Kerschner JL, Roper BB, Bouwes N, Hendersen R, Archer E. 2004. An analysis of stream habitat conditions in reference and managed watersheds on some federal lands within the Columbia River Basin. North American Journal of Fisheries Management 24: 1363-1375.

King RS, Baker ME, Whigham DF, Weller DE, Jordan TE, Kazyak PF, Hurd MK. 2005. Spatial considerations for linking watershed land cover to ecological indicators in streams. Ecological Applications 15: 137-153.

Larsen S, Vaughn IP, Ormerod SJ. 2008. Scale-dependent effects of fine sediments on temperate headwater invertebrates. Freshwater Biology 54: 203-219.

Lennartz S. 2005. Oregon forest land change mapping. 2005, Global Priorities in Land Remote Sensing, Sioux Falls, South Dakota.

Lowe WH, Likens GE, Power ME. 2006. Linking scales in stream ecology. Bioscience 56: 591-597.

Lucero Y, Steel EA, Burnett KM, Christiansen K. In Press. Untangling human development and natural gradients: implications of underlying correlation structure for linking landscapes and riverine ecosystems. River Systematics 19(3): 207-224.

Mac Nally R. 2002. Multiple regression and inference in ecology and conservation biology: further comments on identifying important predictor variables. Biodiversity and Conservation 11: 1397-1401.

Maloney KO, Feminella JW, Mitchell RM, Miller SA, Mulholland PJ, Houser JN. 2008. Land use legacies and small streams: identifying relationships between historical land use and contemporary stream conditions. Journal of the North American Benthological Society 27: 280-294.

Master LL, Stein BA, Kutner LS, Hammerson GA. 2000. Vanishing assets - conservation status of U.S. species. In Precious Heritage: the Status of Biodiversity in the United States, Stein BA, Kutner LS, Adams JS (eds). Oxford University Press: New York; 93-118.

McMahon TE, Hartman GF. 1989. Influence of cover complexity and current velocity on winter habitat use by juvenile coho salmon (Oncorhynchus kitsutch). Canadian Journal of Fisheries and Aquatic Sciences 46: 1551-1557.

Miller RR. 2010. Is the past present? Historical splash dam mapping and stream disturbance detection in the Oregon coast range. MS thesis, Oregon State University, Corvallis, OR.

Montgomery DR, Piegay H. 2003. Wood in rivers: interactions with channel morphology and processes. Geomorphology 51: $1-5$.

Moore KMS, Jones KK, Dambacher JM. 2007. Methods for Stream Habitat Surveys: Aquatic Inventories Project. Oregon Department of Fish and Wildlife Information Report, Salem, Oregon.

National Marine Fisheries Service (NOAA). 1997. Coastal Coho Habitat Factors for Decline and Protective Efforts in Oregon. National Marine Fisheries Service (NOAA), Habitat Conservation Program, Portland, OR.

Nehlsen W, Williams JE, Lichatowich JA. 1991. Pacific salmon at the crossroads: stocks at risk from California, Oregon, Idaho, and Washington. Fisheries 16: 4-21. 
Nickelson TE, Lawson PW. 1998. Population viability of coho salmon, Oncorhynchus kisutch, in Oregon coastal basins: application of a habitat-based life cycle model. Canadian Journal of Fisheries and Aquatic Sciences 55: 2383-2392.

Ohmann JL, Gregory MJ. 2002. Predictive mapping of forest composition and with direct gradient analysis structure and nearest neighbor imputation in coastal Oregon, USA. Canadian Journal of Forest Research 32: 725-741.

Oregon Coastal Salmon Restoration Initiative (OCSRI) Science Team. 1997. Recommendations related to population status. http://Www.oregon-plan.org/OPSW/ archives/reports-subpage.shtml [21 March 1997].

Oregon Department of Forestry. 2004. 1:24,000-scale land ownership in Oregon. Oregon Department of Forestry, Salem, Oregon.

Ott L, Longnecker M. 2001. An Introduction to Statistical Methods and Data Analysis, 5th edn. Wadsworth Group: Pacific Grove, CA.

Pess GR, Montgomery DR, Steel EA, Bilby RE, Feist BE, Greenberg HM. 2002. Landscape characteristics, land use, and coho salmon (Oncorhynchus kisutch) abundance, Snohomish River, Wash., USA. Canadian Journal of Fisheries and Aquatic Sciences 59: 613-623.

Poole GC. 2002. Fluvial landscape ecology: addressing uniqueness within the river discontinuum. Freshwater Biology 47: 641-660.

Rich CF, McMahon TE, Rieman BE, Thompson WL. 2003. Local-habitat, watershed, and biotic features associated with bull trout occurrence in Montana streams. Transactions of the American Fisheries Society 132: 1053-1064.

Richards C, Johnson LB, Host GE. 1996. Landscape-scale influences on stream habitats and biota. Canadian Journal of Fisheries and Aquatic Sciences 53: 295-311.

Roper BB, Buffington JM, Bennett S, Lanigan SH, Archer E, Downie ST, Faustini J, Hillman TW, Hubler S, Jones K, et al. 2010. A comparison of the performance and compatibility of protocols used by seven monitoring groups to measure stream habitat in the Pacific Northwest. North American Journal of Fisheries Management 30: 565-587.

Roper BB, Jarvis B, Kerschner J. 2007. The role of natural vegetative disturbance in determining stream reach characteristics in Central Idaho and Western Montana. Northwest Science 81: 224-238.

Sharma R, Hilborn R. 2001. Empirical relationships between watershed characteristics and coho salmon (Oncorhynchus kisutch) smolt abundance in 14 western Washington streams. Canadian Journal of Fisheries and Aquatic Sciences 58: $1453-1463$.

Smokorowski KE, Pratt TC. 2007. Effect of a change in physical structure and cover on fish and fish habitat in freshwater ecosystems - a review and meta-analysis. Environmental Review 15: 15-41.

Spies TA, McComb BC, Kennedy RS, McGrath MT, Olsen K, Pabst RJ. 2007. Potential effects of forest policies on terrestrial biodiversity in a multi-owner province. Ecological Applications 17:48-65.

Stanley EH, Powers SM, Lottig NR. 2010. The legacy of disturbance in stream ecology. Journal of the North American Benthological Society 27: 67-83.

Steel EA, Feist BE, Larsen DW, Pess GR, Sheer MB, Brauner JB, Bilby RE. 2004. Landscape models to understand steelhead (Oncorhynchus mykiss) distribution and help prioritize barrier removals in the Willamette basin, Oregon, USA. Canadian Journal of Fisheries and Aquatic Sciences 61: 999-1011.

Steel EA, Hughes RM, Fullerton AH, Schmutz S, Young JA, Fukushima M, Muhar S, Poppe M, Feist BE, Trautwein C. 2010. Are we meeting the challenges of landscape-scale riverine research? A review. Living Reviews in Landscape Research 4. http://www.livingreviews.org/lrlr-2010-1

Stevens DL, Olsen AR. 2004. Spatially balanced sampling of natural resources. Journal of the American Statistical Association 99: 262-278.

Thompson WL, Lee DC. 2000. Modeling relationships between landscape-level attributes and snorkel counts of Chinook salmon and steelhead parr in Idaho. Canadian Journal of Fisheries and Aquatic Sciences 57: 1834-1842.

Thompson WL, Lee DC. 2002. A two-stage information theoretic approach to modeling landscape level attributes and maximum recruitment of Chinook salmon in the Columbia River Basin. Natural Resource Modeling 15: 227-257.

Walker GW, MacLeod NS, Miller RJ, Connors KA. 2003. Spatial digital database for the geologic map of Oregon. US Geological Survey, Menlo Park, CA.

Walter RC, Merritts DJ. 2008. Natural streams and the legacy of water-powered mills. Science 319: 299-304.

Wang L, Seelbach PW. 2006. Introduction to landscape influences on stream habitats and biological assemblages. American Fisheries Society Symposium 48: 1-23.

Water and Climate Center of the Natural Resources Conservation Service (WCCNRS). 1998. Oregon Average Monthly or Annual Precipitation, 1961-1990.

Weitkamp LA, Wainwright TC, Bryant GJ, Milner GB, Teel DJ, Kope RG, Waples RS. 1995. Status review of coho salmon from Washington, Oregon, and California. US Department of Commerce, NOAA Technical Memorandum NMFS-NWFSC 24, Seattle, WA.

Wing MG, Skaugset A. 2002. Relationships of channel characteristics, land ownership, and land use patterns to large woody debris in western Oregon streams. Canadian Journal of Fisheries and Aquatic Sciences 59: 796-807.

Wood PJ, Armitage PD. 1997. Biological effects of fine sediment in the lotic environment. Environmental Management 21: 203-217.

Zhang YX, Richardson JS, Pinto X. 2009. Catchment-scale effects of forestry practices on benthic invertebrate communities in Pacific coastal stream ecosystems. Journal of Applied Ecology 46: 1292-1303. 